\title{
Taking Horace to the Yellow Springs: Notes on Death and Alcohol in Chinese Poetry and Philosophy
}

\author{
Jan De Meyer \\ Vivre est une maladie dont le sommeil nous soulage toutes \\ les seize heures. C'est un palliatif. La mort est le remède. \\ CHAMFORT, Suite des maximes générales
}

Among the most powerful of Horace's Odes is that in the second book addressed to a man known as Postumus (the name means "born after his father's death"), which begins with the words Eheu fugaces, Postume, Postume / labuntur anni nec pietas moram / rugis et instanti senectae / afferet indomitaeque morti, or, in the translation by David West:
Ah how quickly, Postumus, Postumus, the years glide by, and piety will not delay the wrinkles, and old age, and death, the unsubdued, pressing at their heels ${ }^{1}$

It is an ode about the passing of time, and even more so about the inevitability of death. Indeed, the poem is a veritable patchwork of death-related imagery and references, including Pluto, ruler of the underworld; cypresses, trees commonly associated with mourning; and Cocytus, one of the rivers surrounding Hades. In Horace's poem, the concept of “afterlife" conjures up images of eternal punishment for those who faulted gravely. Hence the references to the

1 Horace, The Complete Odes and Epodes, tr. David West (Oxford: Oxford Univ. Press, 1997; rpt. 2008), 68. All fragments of this ode cited in the next paragraphs are West's translation. 
arrogant and crafty Sisyphus, forced to roll a boulder up a hill and repeat that into infinity, and to forty-nine of the fifty daughters of King Danaus, eternally punished for having murdered their husbands on their wedding night. But even for those who live pious lives, for those willing to sacrifice three hundred bulls every day in order to placate Pluto, for those who manage not to die in wars or drown in the Adriatic, and for those who care about their health chilly autumn after chilly autumn, death is ineluctable. All of us, "whether we be kings or poor tenant farmers," know that we must cross "those gloomy waters" leading to Hades, writes Horace, and he repeats this message twice: "We must go and see black Cocytus meandering in its sluggish flow," and again, "We must leave the earth, our home, and the wife we love."

The grimness of this ode is hardly mitigated by the evocation, in the final lines, of one of the best wines known to Horace and his contemporaries of the first century вСЕ, a strong, sweet white wine from coastal Latium:

Your heir, worthier than yourself, will drink off the Caecuban you laid down behind a hundred locks, and stain your paving with proud wine undiluted and too good for the banquets of priests.

If any consolation is to be found in these final verses, it would seem to be a meager one. Once one has left this earth, one is no longer conscious of what will happen to one's most treasured belongings: Postumus' heir will stain the paving with the precious Caecuban wine that once rested "behind a hundred locks." To some, the poem's tone here merely moves from grim to sneering, but others interpret its conclusion as an exhortation to do exactly as Postumus' worthier heir will, and drink wine while one still can. To me, this ode brings to mind certain passages from classical Chinese literary sources that deal with the realization of the brevity of life and what may be done in order to assuage the potential feelings of frustration resulting from it. I will turn to two genres that may seem unrelated — philosophy and poetry—but which often touch upon common themes.

\section{Zhuangzi's Equanimity in the Face of Death}

Death and alcohol—and a few related images—being our main concern, we shall devote no attention to arguments in favor of the non-existence of death. "Human existence being an hallucination containing in itself the secondary hallucinations of day and night (the latter an insanitary condition of the 
atmosphere due to accretions of black air) it ill becomes any man of sense to be concerned at the illusory approach of the supreme hallucination known as death," says De Selby at the outset of Flann O'Brien's The Third Policeman, but, just like the argument that man (meant is his physical person) cannot die because he has always been dead, developed by the ninth-century Daoist Wunengzi 无能子 ("Master Incompetent"), we will not discuss them in these pages. $^{2}$

The eighteenth chapter of the Zhuangzi 莊子, titled "Perfect Happiness," contains a famous anecdote relating a conversation between Zhuangzi and his friend Hui Shi 惠施, a philosopher ranked among the Dialecticians ("School of names," mingjia 名家). Zhuangzi has just lost his wife, and when Hui Shi visits him in order to convey his condolences, he finds Zhuangzi sitting with his legs stretched out and singing a song while accompanying himself by beating on a tub-hardly the sort of behavior one would expect from a mourning man. When Hui Shi remarks that Zhuangzi is excessive in his seeming lack of respect, Zhuangzi replies, in Burton Watson's translation:

“You're wrong. When she first died, do you think I didn't grieve like anyone else? But I looked back to her beginning and the time before she was born. Not only the time before she was born, but the time before she had a body. Not only the time before she had a body, but the time before she had a spirit. In the midst of the jumble of wonder and mystery a change took place and she had a spirit. Another change and she had a body. Another change and she was born. Now there's been another change and she's dead. It's just like the progression of the four seasons, spring, summer, fall, winter. Now she's going to lie down peacefully in a vast room. If I were to follow after her bawling and sobbing, it would show that I don't understand anything about fate. So I stopped."

\section{不然。是其始死也, 我獨何能无概然! 察其始而本无生, 非徒无生也 而本无形, 非徒无形也而本无氣。雜乎芒芴之間, 變而有氣, 氣變而 有形, 形變而有生, 今又變而之死, 是相與爲春秋冬夏四時行也。人 且姮然寝於巨室, 而我噭噭然隨而哭之, 自以爲不通乎命, 故止也。}

2 As yet, there is no good English-language translation of Wunengzi, only the very imperfect rendition in John A. Rapp, Daoism and Anarchism: Critiques of State Autonomy in Ancient and Modern China (London: Continuum, 2012), 231-62. In Dutch there is the translation by De Meyer, Nietskunner: Het taoïsme en de bevrijding van de geest (Amsterdam: Augustus, 2011). The argument mentioned above is, respectively, on pp. 236 and 69.

3 The Complete Works of Chuang Tzu, tr. Burton Watson (New York: Columbia Univ. Press, 1968), 192. 
Equanimity in the face of death is a theme often encountered in the Zhuangzi, and on some occasions, the dying are even portrayed as capable of a measure of good-humored wonderment, as in the sixth chapter ("The Great and Venerable Teacher"), where we meet four sages - Masters $\mathrm{Si}, \mathrm{Yu}$, Li, and Lai-who become friends, as all four of them understand that "death and life, existence and extinction, form one single body” (死生存亡之一體者). When Master Yu falls ill, he exclaims: "Amazing, how the Fashioner of Things is making me all bent and contorted like this!" (嗟乎! 夫造物者又將以予爲此拘拘也) When Master Si asks him if his condition is cause for resentment, Master Yu answers that it is not, and he fantasizes about how different parts of his body will be transformed into new beings after his death. One obtains life, he also explains, when one's time has come, and one loses life because that is the natural order of things. Finding peace in this means that neither sorrow nor joy are able to enter. Some time later, it is Master Lai's turn to fall ill. When he is about to breathe his last, and his wife and children surround him sobbing, Master Li enjoins them to go away so as not to disturb the transformation (hua 化). ${ }^{4}$

The acceptance of death as part of a greater natural process is thus intimately related to the awareness of the necessity of change and transformation. The equanimity resulting from it is what the ancients called "liberation from being suspended" (xuanjie 懸解), with "being suspended" having connotations of worries and anxieties. But who, save for a true sage, would be capable of Master Yu's detachment and self-control? In the opening paragraphs of the sixth Zhuangzi chapter ("The Great and Venerable Teacher"), the ability to remain emotionally unaffected by life and death is attributed to the Perfected Men of Antiquity (gu zhi zhenren 古之真人). In the Zhuangzi, this term indicates one of the highest categories of human beings, beings so fully realized that, though they might have had the appearance of man, they were actually inhabited by the emptiness of Heaven (ren mao er tian xu 人貌而天虛). ${ }^{5}$ In the spiritual hierarchy of Daoist religion, the appellation of "Perfected" was reserved for beings ranked even higher than the immortals (xian 仙, also translated as "transcendents"). But what about us mortals, who may not yet have liberated ourselves from being suspended?

4 Ibid., 83-85.

5 The description is from Zhuangzi 21 ("Tian Zifang”); ibid., 221. 
In a number of passages from another Daoist classic, the Liezi 列子, we encounter an attitude toward death quite different from that in the Zhuangzi, an attitude that brings us closer to Horace's ode. These passages are found in the Liezi's penultimate chapter, titled “Yang Zhu” 楊朱, in reference to the philosopher of that name who became infamous in Confucian as well as in Mohist circles for his perceived egoism or hedonism: he is remembered by many as the philosopher who refused to sacrifice one single hair on his body in order to save the world. ${ }^{6}$ The Liezi is a curious book in eight chapters, that may contain materials ranging from ca. $300 \mathrm{BCE}$ to ca. $300 \mathrm{CE}$. Some of the oldest fragments of the book are believed to have originally belonged to the Zhuangzi in fiftytwo chapters, that was cut down to its current size (thirty-three chapters) around $300 \mathrm{CE}$. But quite a high percentage of the text must be from the third century $\mathrm{CE}$, and that helps to explain the apparent differences in worldview we encounter throughout the book, e.g., why Liezi's first chapter stresses the acceptance of death, and the sixth chapter is largely fatalistic in tone, whereas many anecdotes in the seventh chapter advise one to enjoy wine and women, because life is short and the things we do in order to gain a good reputation for ourselves are, in the final analysis, utterly futile.

In the previous sentence I spoke of "apparent differences" because I am convinced that, despite the presence of many diverging voices throughout the Liezi - and in the "Yang Zhu" chapter in particular, where we hear both a "Daoist" and a "hedonist" Yang Zhu, and perhaps even a few others—a rather coherent vision underlies the book as a whole. To limit our discussion to the "Yang Zhu" chapter, it is noteworthy that when the "hedonist" Yang Zhu is speaking, his hedonism is frequently tempered by considerations regarding the equality of life and death, the futility of striving for wisdom and fame, the necessity of acting spontaneously (ziran 自然, "so-out-of-itself") and without

6 Yang Zhu was derided by both Confucians and Mohists because they were unable to grasp the meaning of his reaction to a question by the Mohist Qin Guli 禽滑嶅. When Qin Guli asks Yang Zhu whether he would cut off a single hair from his body in order to save the world, Yang answers that the world can certainly not be saved by one single hair. "But supposing it could save the world, would you do it?" insists Qin. Yang Zhu refrains from replying. Mengsun Yang 孟孫陽, a disciple of Yang Zhu, continues the discussion with Qin Guli, defending the viewpoint that even a single hair has its importance and must not be looked down upon. The historical Yang Zhu espoused a philosophy not of egoism or hedonism but of absolute respect for the integrity of every living being, coupled with the conviction that in a world well-ordered, even the sacrifice of one single hair would be superfluous. See Angus C. Graham, The Book of Lieh-tzu (London: John Murray, 1960), 148-49 and Jan De Meyer, De geschriften van Liezi (Amsterdam: Augustus, 2008), 184-85. 
ulterior motives (wuwe $i$ 無爲, also: "non-action," “non-interference”) and regarding the prison that is conformism, in other words, arguments that one may also encounter in the writings attributed to Laozi 老子 and Zhuangzi. At times, the "hedonist" Yang Zhu's cogitations about the brevity of life, and what little time we have to ourselves because of all the days, months, and years we waste on things non-essential, come very close to what the Stoic Seneca wrote in his De brevitate vitae. ${ }^{7}$

One long passage from the seventh Liezi chapter is of particular significance to us here, as it combines the themes of the elusiveness of life and the pleasure found in alcohol (as well as in sex). Its protagonists are Zichan 子產 (courtesy name of Gongsun Qiao 公孫僑, prime minister of the state of Zheng 鄭 in the second half of the sixth century BСE), his older brother, Gongsun Chao 公孫朝, and his younger brother, Gongsun $\mathrm{Mu}$ 公孫穆. After having brought order to his state, Zichan continuously worries about the behavior of his two brothers. $\mathrm{Mu}$, the younger one, is addicted to women, and Chao, the older one, to wine. This is how Angus Graham translates the Liezi's description of Gongsun Chao:

Chao had collected in his house a thousand jars of wine and a whole hillock of yeast for brewing; and for a hundred paces outside his door the smell of the dregs came to meet men's nostrils. When he was carried away by wine, he did not know whether there was peace or war in the world, he did not notice mistakes which he had time to repent, he forgot the possessions in his own house, the degrees of affinity of his kinsmen, and that it is better to live than to die. Even if he had stood in water or fire with sword blades clashing before him, he would not have known it. ${ }^{8}$

\section{朝之室也聚酒千鍾, 積麳成封, 望門百步, 糟漿之氣逆於人鼻。方其 荒於酒也, 不知世道之安危, 人理之悔客, 室內之有亡, 九族之親 疏, 存亡之哀樂也。雖水火兵刃交於前, 弗知也。}

In an attempt to bring his brothers to reason, Zichan pays them a visit, promising them that if they live properly and with a sense of duty, they will gain for themselves a good reputation and high office. The brothers reply by saying that life is only obtained with difficulty, whereas death catches up with one easily, and that it makes no sense for a man with an easily lost life to sit around and wait for death. The brothers have made their choice: to enjoy to the full the single life that is theirs. But their reasoning does not end there. Looking upon

7 Graham, Lieh-tzu, 139-40.

8 Ibid., 144. 
the way in which they give in to their respective passions as a means of acting in accordance with their own nature, and thus of "ordering themselves," they compare themselves favorably to their deadly serious brother:

He who is good at ordering what is outside himself will personally encounter bitterness, whereas the other beings will not necessarily be brought to order. He who is good at ordering his own interior sets his nature free, without necessarily bringing disorder to the lives of other beings. Your method of ordering what is outside yourself may be put into practice temporarily in a single state, but it doesn't correspond with men's minds. Our method of ordering ourselves may be extended to all under heaven, and the Way of ruler and subject will be brought to rest.

\section{夫善治外者, 物未必治, 而身交苦。善治內者, 物未必亂, 而性交 逸。以若之治外, 其法可暫行於一國, 未合於人心。以我之治內, 可 推之於天下, 君臣之道息矣。}

Let us be clear about one thing: Zichan's brothers are not advising everybody on the planet to become addicted to wine or women, but to give freedom ( $y i$ 逸, also translated as "uninhibited," "unconfined," or "unattached") to their own nature, whatever that nature may be. Some will find out that they excel at carpentry or at catching cicadas, others that they are good swimmers, and still others will develop the art of butchering oxen to such a level that they will be able to use the same knife for nineteen years without having to sharpen it even once. ${ }^{9}$ Some, like Zichan's brothers, will become fornicators and inveterate wine bibbers, but as long as they do what they like to do in a way that doesn't harm others, they are just parts of the seeming Chaos that is the natural order. The brothers' final words are an indication that this fragment of the Liezi is quite late, probably belonging to the third century: in that era, the topic of ending or "bringing to rest" the Way of ruler and subject - in other words, espousing anarchism - was hotly debated..$^{10}$ But I fear we are straying from our topic. We started out with poetry on death and wine, and to poetry on death and wine we shall return.

$9 \quad$ All examples of self-cultivation as found in the Zhuangzi.

10 See, e.g., Etienne Balázs, "Entre révolte nihiliste et évasion mystique: Les courants intellectuels en Chine au IIIe siècle de notre ère," Etudes asiatiques 2 (1947-48): 27-55, and Jean Lévi, Eloge de l'anarchie par deux excentriques chinois (Paris: Editions de l'encyclopédie des nuisances, 2004), which contains (pp. 33-54) a full translation of chapter 4 of the Baopuzi waipian 抱朴子外篇 by Ge Hong 葛洪 (283-343), consisting of a discussion of the ideas of the proto-anarchist Bao Jingyan 鮑敬言. 
A very fitting point of departure is the group of "Nineteen Old Poems from the Han" (Gushi shijiu shou 古詩十九首), also known affectionately as the "Mother of poetry" (shimu 詩母). Traditionally considered the oldest examples of pentasyllabic Chinese verse, these poems may have been composed during the Eastern Han dynasty $\left(25^{-220}\right)$. Anonymous and without indication of the speaker's gender, the old poems are clearly indebted to folk songs as well as to the poetry of the Book of Odes (Shijing 詩經) and the Songs of the South (Chuci 楚辭). Highly influential in the shaping of shi-poetry, the old poems owe their immense popularity to the way in which they manage to express universal emotions. Separation and death are the major themes of the Nineteen Old Poems, and, as Jean-Pierre Diény stresses in his masterful study and translation, many links tie these two themes together. ${ }^{11}$

The brevity of life is coupled with an exhortation to drink wine in the third of the Nineteen Old Poems. The relevant fragment (verse 3 to 6), translated below, opens with a nod to chapter 22 of the Zhuangzi ("Knowledge Wandered North"), where we read: "Man's life between heaven and earth is like the passing of a white colt glimpsed through a crack in the wall: all of a sudden it's gone" (人生天地之間, 若白駒之過卻, 忽然而已). ${ }^{12}$
人生天地間,
Man's life, between heaven and earth,
忽如遠行客。 speeds by like a traveler with a long road to go.
斗酒相娛樂, Let this peck of wine bring merriment to us;
聊厚不爲薄。 a moment of generosity, not to be despised.

A poignant image of life's impermanence is found in Old Poem number 4: "Man's life: a temporary stay, one generation long / sudden and swift like dust in a whirlwind" (人生寄一世, 奄忽若颷塵). And in the eleventh Old Poem we read: "Man's life is neither metal nor stone / How would one be able to lengthen one's life span?” (人生非金石, 豈能長壽考) Nowhere do we find more parallells with Horace's ode, however, than in Old Poem number 13, which I translate in its entirety:

驅車上東門, Spurring on my carriage, past the Upper Eastern Gate, 遙望郭北墓。 I gaze at distant graves, north of the outer walls.

白楊何蕭蕭， White poplars—how they rustle in the wind!

\footnotetext{
$11 \quad$ Jean-Pierre Diény, Les dix-neuf poèmes anciens (1963; rpt. Paris: Les Belles Lettres, 2010).

12 Tr. Watson, Complete Works of Chuang Tzu, 240.
} 
松柏夾廣路。

下有陳死人, 查杳即長暮。 潛然黃泉下, 千載永不寤。 浩浩陰陽移, 年命如朝露。 人生忽如寄, 壽無金石固。 萬歲更相送, 賢聖莫能度。 服食求神仙, 多爲藥所誤。 不如飲美酒 , 被服級與素。
Pines and cypresses at both sides of the avenue. Beneath them are people who died long ago, in the dark and gloom of the enduring night. Deep they sleep, down by the Yellow Springs, never to be woken, not in a thousand years. Vast and endless is the shifting of yin and yang, our fate-allotted years are like the morning dew. Man's life speeds by, a temporary stay, his days lack the solidity of metal or stone. Ten thousand years have been seeing each other off, yet no worthy or sage was able to find a cure. ${ }^{13}$ Ingesting substances, some seek immortality, but many have been deluded by their medicine. Better it is to drink an excellent wine, and clothe ourselves in fine white silk.

The Upper Eastern Gate has been associated with Luoyang 洛陽, the capital under the Eastern Han dynasty, and the "distant graves, north of the outer walls" refer to the hill known as Beimang 北印, where Luoyang's dead were buried for countless generations. Besides the common theme of life's impermanence, the three elements connecting Horace's ode with the thirteenth Old Poem are the cypresses as markers of gravesites, the reference to excellent wine, and the mention of the underworld, which in ancient China was known as the Yellow Springs (huangquan 黃泉). Huangquan is an interesting name, as it combines earth or soil (the color of which is yellow) with the watery element of the spring. The oldest occurence of the Yellow Springs as a place for the dead is in the ancient narrative history known as the "Tradition of Zuo" (Zuozhuan 左傳), first year of Duke Yin 隱公 (c. BC 721). ${ }^{14}$ It is also known as the "Nine Springs” (jiuquan 九泉), perhaps because jiu 九 (“nine”) was pronounced in a similar fashion to jiu 久, meaning "persistent." He who enters the realm of the dead, will forever be the resident of the "terrace of enduring night" (changyetai 長夜臺), as the grave was often called.

13 This line about the powerlessness of worthies or sages when confronted with death was echoed in the third of Tao Yuanming's 陶淵明 pallbearers' songs (wan'ge 挽歌), beautifully translated in all its starkness by Wai-lim Yip, Chinese Poetry: An Anthology of Major Modes and Genres (Durham, N.C.: Duke Univ. Press, 1997), 111.

14 For a useful overview of early occurences of huangquan in literature, see Jue Guo, "Concepts of Death and the Afterlife Reflected in Newly Discovered Tomb Objects and Texts from Han China," in Mortality in Traditional Chinese Thought, ed. Amy Olberding and Philip J. Ivanhoe (Albany: State Univ. of New York Press, 2011), 109-10, n. 49. 
Searching for more classical Chinese verse combining death, the underworld, cypresses, and wine, I came upon a poem by Li He 李賀 (79o-816), one of the most singular voices in Tang dynasty poetry-perhaps even in the entire history of classical Chinese literature. There is something almost violent in the wild flights of Li He's shamanism-influenced imagination, causing literary critics to describe his poetry as "demonic" and resulting in centuries of relative neglect, until his rediscovery in the twentieth century. ${ }^{15}$ The title of the poem in question is "Song by Palace Lady Tang of the Han while the Wine is Drunk" (Han Tang ji yinjiu ge 漢唐姬飲酒歌), and in order to fully understand what is being said, some background information and additional explanation are, alas, necessary. Palace Lady Tang 唐姬 was the spouse or concubine of Liu Bian 劉 辯, the penultimate Eastern Han emperor, who is remembered as Shaodi 少帝, the "Young Emperor." In the fourth lunar month of 189, Liu Bian was put on the throne, aged 13. Barely five months later, he was deposed by the ruthless Dong Zhuo 董卓 (?-192), a warlord who wanted to replace Liu with another, even younger, member of the imperial clan (Liu Xie 劉協, aged 8), and who appointed himself prime minister. Early in the year 19o, Dong Zhuo forced Liu Bian to commit suicide by drinking poisoned wine. Li He's poem is a recreation of the song which Palace Lady Tang may have sung to her husband while she danced for him during the final farewell banquet in the palace.

御服沾霜露, The emperor's clothes are imbued with frost and dew, 天唯長蓁棘。 On Heaven's Crossroads, ${ }^{16}$ long thorns proliferate.

金隱秋塵姿，When gold lies hidden beneath autumn's dust,

4 無人爲帶飾。 No one will use it as an ornament for one's belt.

玉堂歌聲葠, In jade halls, the sound of singing lies down to sleep,

芳林煙樹隔。 In fragrant forests, fog separates the trees.

雲陽臺上歌, A song from Yunyang ${ }^{17}$ Terrace:

8 鬼哭復何益。

A ghost wailing, to no one's benefit.

鐵劍常光光, Iron swords forever shine and glow, 18

兇威屢脅逼。 Fiendish forces repeatedly menace.

See J.D. Frodsham's translation of Li He's entire poetic œuvre, The Collected Poems of Li He (1970; rpt. Hong Kong: Chinese Univ. Press, 2016). The translation of this poem is on p. 275. Heaven's Crossroads (tianqu 天忂) is here to be understood as the avenues of the imperial palace.

17 Yunyang 雲陽, where criminals were executed when Li Si 李斯 (died 208 BCE) was prime minister of the Qin 秦 dynasty (221-206 BCE), may here be understood as “jail.” 


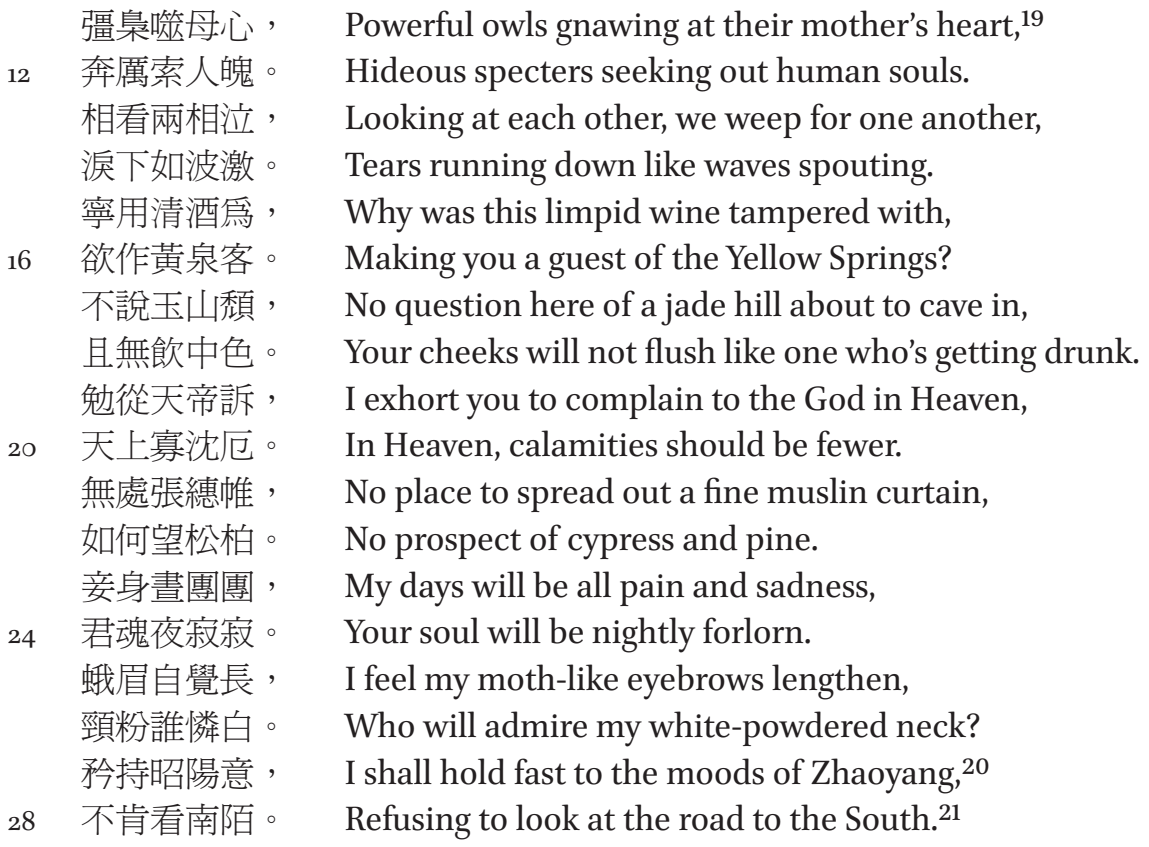

Li He's poem is a clever mix of outbursts of sadness, loneliness, and indignation, as well as images of death. Some of the allusions are very clear: when we read about a "ghost wailing," we know that the Young Emperor is meant, and we understand that when powerful mother-eating owls and "hideous specters seeking out human souls" are mentioned, the cruel Dong Zhuo is meant. Two allusions are of a more hidden kind, but very interesting as they both point toward an unjust or undeserved death. The first is in the initial verses of the poem (The emperor's clothes are imbued with frost and dew / On Heaven's Crossroads, long thorns proliferate). These lines are inspired by a passage from the biography of Liu An 劉安 (179-122 BCE), the Prince of Huainan 淮南王, under whose auspices the Huainanzi 淮南子 was written and compiled. ${ }^{22} \mathrm{As}$ is well known, Liu An commited suicide after accusations of treason. The second

19 It was believed that some species of owls ate their mother once they had reached adulthood. In China, the owl is an inauspicious bird.

2o Zhaoyang 昭陽 was one of the imperial palace halls under the Han.

21 Palace Lady Tang hailed from Yingchuan 穎川 I, southeast of Luoyang. If the Lady is suggesting she will not return to her hometown in order to remain closer to her murdered husband, this does not tally with the recorded facts. Lady Tang did return to Yingchuan, but refused to remarry.

22 Compare the lines 今臣亦見宮中生荆棘, 露露衣也 in Shiji 史記 (Beijing : Zhonghua shuju, 1972), 118.3085 . 
allusion is in the line "No question here of a jade hill about to cave in." According to the great early-fifth century collection of anecdotes Shishuo xinyu 世說 新語, the poet, musician, philosopher, and great drinker Ji Kang 嵇康 (223262) — together with Ruan Ji 阮籍 (210-263) the most famous of the Seven Sages of the Bamboo Grove 竹林七賢—resembled "a jade hill about to topple" when he was drunk. ${ }^{23}$ Outspoken and defiantly unconventional as he was, Ji Kang once angered an official, who later took his revenge when Ji Kang came to the defense of a friend who had been wrongfully accused. Both Ji Kang and his friend were sentenced to death and executed.

\section{A Poetic Philosophy of Wine}

The previous pages have taken us from philosophical considerations about the brevity of life and the acceptance of death to poetry in which the insight into life's impermanence is teamed up with exhortations to drink. An interesting question is: is there any common ground between Zhuangzi's philosophical acceptance of death, on the one hand, and the perceived escapism of the Nineteen Old Poems of the Han, where alcohol brings temporary solace but little more, on the other? Or, to put it in other words, is there some form of poetic philosophy of wine, where drinking is taken not as a means to forget the human condition but as leading to a higher understanding allowing one to be at peace with it? The answer is yes, and the first poet to effectuate this was Tao Yuanming 陶淵明 (365-427), also known as Tao Qian 陶潛. A poem by Tao, titled "Drinking alone in continuous rain" (Lianyu duyin 連雨獨飲) and translated below, demonstrates this very nicely. It opens with a statement about the cyclical experience of time and life, whereby death, the end, is seen as a return, and it questions the existence of immortality. "Song and Qiao" are Chisongzi 赤松子 and Wangzi Qiao 王子喬, two legendary immortals of Chinese antiquity frequently mentioned together since Han times. Tao Yuanming, who cannot believe that immortals could exist in the world of his day, shifts his attention to the wine given to him by an old man, with the promise that drinking it can confer immortality. Tao tries a few cups, and the experience he then describes could come straight out of the Zhuangzi. All thoughts (or worries) disappear, and even Heaven is forgotten. Heaven (tian 天), it should be pointed out, is not to be understood here as primarily indicating the realm of the gods

23 Xu Zhen'e 徐震堮, Shishuo xinyu jiaojian 世說新語校箋 (Beijing: Zhonghua shuju, 1984), 14.335; Richard B. Mather, Shih-shuo Hsin-yü: A New Account of Tales of the World, 2nd ed., rev. (Ann Arbor: Center for Chinese Studies, Univ. of Michigan, 2002), 331. 
but rather as Nature. Heaven-as-Nature surrounds and penetrates all that exists, and can therefore never be "removed from all this," even though it may at times be forgotten. The advice which Tao gives us - to trust in what's True-is very close to Zhuangzi's philosophy of Nature. What is True (zhen) is what is "realized" or "perfected"; it is the quality distinguishing the "Perfected Men of Antiquity"-humans who have developed to perfection the talents which Nature has endowed them with. Also the final verses are steeped in Zhuangzi's thought: although Tao realizes that his body has been transforming (like that of Masters Yu and Lai mentioned above) ever since achieving the "solitary" state of every individual human being, consolation comes from the fact that his mind ( $x$ in 心) is still there.

運生會歸盡, 終古謂之然。 世間有松喬, 於今定何間。 故老贈余酒, 乃言飲得仙。 試酌百情遠,

8 重觞忽忘天。 天豈去此哉, 任真無所先。 雲鶴有奇翼，

八表須鼠還。 自我抱茲獨, 伡俛四十年。 形䯚久已化, 16 心在復何言。
Whatever is fated to live will return to its end: Since earliest times this is said to be so. If Song and Qiao ever lived in this world, Where would they be staying now? The old fellow who gave me this wine, Said that drinking it makes you immortal. I try a cup, and all my thoughts are far away, Pour another one, and suddenly I forget Heaven. But how could Heaven be removed from all this? Trust in what's True - there is no better way. The cloud-crane, with its wondrous wings, Reaches outer space in the blink of an eye. Since I first embraced my solitude, I've been toiling for forty years. ${ }^{24}$ Long since, my body's been transforming, But my mind is here-what more needs to be said?

Tao Yuanming had countless followers and imitators, but few developed Tao's attitude toward alcohol in the way Wang Ji 王績 (c. 59o-644) did. ${ }^{25}$ Wang Ji was

24 Tao Yuanming's toiling would last two more decades. The poet died in his sixty-third year, or the "grand climacteric year" as it is known to some. Climacteric years are multiples of seven or nine, and it is believed that they present more dangers than other years. Two remarkable works of contemporary French literature, both written by mathematician, poet, and prominent Oulipo member Jacques Roubaud (born 1932), were inspired by climacteric misgivings, at ages 63 ( 7 times 9) and 81 (9 times 9): L'abominable tisonnier de John McTaggart Ellis McTaggart et autres vies plus ou moins brèves (Paris: Seuil,1997), and Octogone: Livre de poésie, quelquefois prose (Paris: Gallimard, 2014).

25 For a history of the reception of Tao Yuanming's poetry, see Wendy Swartz, Reading Tao Yuanming: Shifting Paradigms of Historical Reception (Cambridge, Mass.: Council on East 
the younger brother of Wang Tong 王通 (c. 584-617), a well-known Sui 隋 dynasty Confucian scholar. After three false starts in official life, Wang Ji, also known as Wang Wugong 王無功, that is, Wang-without-merit, retired to the family estate in order to write and drink profusely. About one third of Wang Ji's collected works is devoted to alcohol, and the theme pervades all literary genres practiced by Wang: poetry, short prose, and letters. A "Rhapsody on Alcohol" (Jiu fu 酒賦) is lost, but fortunately we still possess Wang's idealized self-portrait, the "Biography of Master Five Dippers" (Wudou xiansheng zhuan 五斗先生傳), ${ }^{26}$ and the magnificent "Record of Drunkland" (Zuixiang ji 醉郷 記), besides dozens of poems, some of them reportedly written on the walls of the taverns where Wang Ji used to get drunk. It is important to stress that, in these writings, Wang Ji develops a veritable philosophy of inebriation, wherein, as Ding Xiang Warner explains, drunkenness becomes a metaphor for enlightenment. ${ }^{27}$ Knowing that all these wonderful literary creations exist, and being able to relish and study them, at times aided by a glass of red Graves, therein lies the real consolation to me, until the mind gives in, or up, or out, and we are ready to enter our graves.

Asian Studies, Harvard Univ., 2008). For Tao's influence on Wang Ji, see pp. 161-63.

26 The name is a nod toward Tao Qian, who was also known as Master Five Willows (Wuliu xiansheng 五柳先生).

27 Warner, A Wild Deer among Soaring Phoenixes: The Opposition Poetics of Wang Ji (Honolulu: Univ. of Hawaii Press, 2003), 89. 